\title{
English sentences beginning with there and their Vietnamese counterparts
}

\section{Thanh Minh To}

Faculty of English Linguistics and Literature, University of Social Sciences and Humanities, Vietnam National University - Ho Chi Minh City, Vietnam

\section{Email address:}

minhthanhto@gmail.com,minhthanhto@hcmussh.edu.vn

\section{To cite this article:}

Thanh Minh To. English Sentences Beginning with there and their Vietnamese Counterparts. International Journal of Language and Linguistics. Vol. 2, No. 6, 2014, pp. 391-402. doi: 10.11648/j.ijll.20140206.19

\begin{abstract}
English sentences beginning with there, also called English there-constructions, do not constitute only existential sentences; most important among their other uses are presentational there-constructions. It is almost impossible to distinguish existential sentences beginning with Empty there, which is not stressed and has no lexical meaning, from presentational thereconstructions beginning with Locative there, which is pronounced with some degree of stress and has its denotative meaning as opposite to that of the adverb here. Therefore, language users have to care for other sentence components, both obligatory and optional, that follow there in the clause in question. Comparing English there-constructions and their Vietnamese counterparts helps to identify translated versions of each subtype of English there-constructions, both semantically and pragmatically equivalent, irrespective of the fact that Vietnamese has neither the empty subject nor subject-verb inversion - the two phenomena quite easily observed in a Subject-prominent language like English.
\end{abstract}

Keywords: English there-Constructions, Existential Sentences, Presentational there-Constructions, Empty there, Locative there

\section{Introduction}

Language and culture are twins. To make native speakers of Vietnamese perceive the meaning of the sentence "Tom eats like a horse" in the same way as native speakers of English, the Vietnamese version of the sentence is not "Tom ăn như một con ngựa" but "Tom ăn như lợn"1, which is closely related to the rice culture in South East Asia. Hopefully, the differences between western and eastern cultures can be bridged if we continue to communicate partially via interlingual translation. English sentences beginning with there and their Vietnamese counterparts, which is the focus of this paper, illustrates an effort to meet the demanding requirements of translation practice interlingually and cross-culturally.

\section{Literature Review}

\subsection{Interlingual Translation}

"Interlingual translation or translation proper is an

${ }^{1}$ which literally means "Tom eats like pig" interpretation of verbal signs by means of some other language."2

The important role of interlingual translation in teaching a foreign language has been emphasized: it "helps students to understand the connection between languages and explores the potential of both of them. It is a necessary and natural activity, because in many common places foreign words are met and they need to be decoded. Communication accomplishment is a two-way system. Learners need to be able to communicate both ways: into and from the foreign language. In most materials used on lessons they are pressed mostly on the ability of using a foreign language, but little guidance is given on how to transmit it back into the mother tongue."3

Accordingly, more guidance is of urgent need to bridge the gap between theory of interlingual translation and translation practice as well as between researches in linguistics and those in interlingual translation, as far as the two natural languages called English and Vietnamese are concerned. This is definitely true in Vietnam nowadays, as the so-called

${ }^{2} \mathrm{https}: / /$ www.google.com.vn/\#q=interlingual+translation+definition

${ }^{3}$ http://spswiatki.edu.pl/archiwum/publikacje/translation.pdf 
developing country has been struggling hard to integrate into the world verbally via an international language like English.

This paper proves to be an effort to provide linguistic data for the BA program in English Linguistics and Literature ${ }^{4}$ currently applied at the University of Social Sciences and Humanities, Vietnam National University - Ho Chi Minh City, Vietnam, to facilitate the teaching and learning process there in general and to support the Translation-Interpretating Section in particular.

This paper is also oriented to Vietnamese communities in English-speaking countries throughout the world with the hope of continually nurturing any effort to maintain the mother tongue of generations of the Vietnamese people overseas.

\subsection{Studies of English there-Constructions and their Counterparts in other Languages}

According to Halliday (1994: 38) [1] "Theme ${ }^{5}$ is "the starting-point for the message." A halfpenny is Theme in $a$ halfpenny is the smallest English coin ('I'll tell you about a halfpenny') while the smallest English coin is Theme in the smallest English coin is a halfpenny ('I'll tell you about the smallest English coin).

In the same vein, Grzegorek (1984: 144) [2] treats Theme in English as "the left-most constituent of a clause" that is "capable of referential use or at least capable of contextually bound." Accordingly, "do not count as themes" are "all sentence adverbials in clause-initial position", including Locative there, which is pronounced with some degree of stress, means "in that place" and begins English presentational there-constructions; neither does Empty there, which is not stressed, has no lexical meaning and begins English existential sentences. In other words, both Empty there and Locative there mark English clauses in question as "themeless."

Semantically speaking, Grzegorek [2: 145, 148] distinguishes two main types of English there-constructions:

1. English existential sentences - those which are obligatory themeless by virtue of grammar (grammar of English offers no other choice) and whose function is "to assert the existence of the referent the displaced subject NP":

(1) There ARE no ghosts. ${ }^{6}$

(2) There DEVELOPED a serious crisis.

(3) There ENTERED a strange-looking man.

\footnotetext{
${ }^{4}$ http://nva.hcmussh.edu.vn

5 which is also called "Topic" in English [1:38] and "Chủ đề" in Vietnamese

${ }^{6}$ It is necessary to indicate now a number of conventions applied in this paper:

- The optimal Vietnamese equivalent version or versions will be placed right under its or their original English there-construction in question;

- The lexical items in round brackets, like "(there)" in (47) and (48), may or may not be verbalized, while those in square brackets are embedded clauses, like "[as if there'S a tap running somewhere]" in (25);

- The three symbols "^”, “*”, and "?" respectively stand for "or," "unaccepted," and "possibly accepted";

- Adverbials are in italic;

- English VERBS, either one-word or multiple-word, and their Vietnamese EQUIVALENTS are capitalized.
}

(4) There WERE beautiful flowers all over the place.

(5) There IS a difference between the two signs.

(6) There WAS a rumor that the president was killed.

(7) On the platform there WERE many women who waited for their husband.

2. English presentational there-constructions - those which have thematic counterparts, and the choice between thematic and non-thematic construction depends on typical factors such as context and the way the speaker presents a give event and whose function is "to raise the referent of the subject to the addressee's consciousness":

(8) There STEPPED OUT in front of the car a small child.

(9) There CAME into his view Irene.

(10)All of a sudden there BURST IN his younger sister Jane.

Accordingly, for every English presentational thereconstruction we have a corresponding thematic sentence:

(11) A small child STEPPED OUT in front of the car.

(12) Irene CAME into his view.

(13) His younger sister Jane BURST IN all of a sudden.

Syntactically speaking, Grzegorek [2: 147] classifies English there-constructions according to:

1. Their type of main verb:

a. be;

b. verbs other than be but of related meaning (appear, emerge, occur, develop, remain);

c. some stative verbs describing location (hang, lie, stand) and some verbs of directional movement (step out, burst in, walk into).

2. The structure of the noun phrase (abbreviated to NP) following the verb:

a. without any modifier, like the example numbered (1);

b. with a modifier of various types:

- adjective, like the examples numbered (2), (3) and (4);

- prepositional phrase (like the example numbered (5);

- relative clause (like the examples numbered (6) and (7).

Grzegorek [2: 155-166] then presents counterparts of English there-constructions in Polish.

The study reported in this paper obtained with careful selection the results of Grzegorek's study [2] to search for counterparts of English there-constructions in Vietnamese, a natural language whose prominent clause structure is not Subject-Predicate ${ }^{7}$ but Topic-Comment ${ }^{8}$, as mentioned by Hao Xuan Cao (1991) [3].

Up to now there have been a number of studies done in Vietnam and based on the theory of the Topic-Comment structure in the Vietnamese language supported by Hao Xuan Cao [3]; however, nothing has been done to compare and contrast English there-constructions and their counterparts in Vietnamese.

\footnotetext{
7 called "cấu trúc Chủ-Vị” in Vietnamese

${ }^{8}$ called "cấu trúc Đề-Thuyết" in Vietnamese
} 


\section{Aims of the Study}

"Translation is like a woman. If it is beautiful, it is not faithful. If it is faithful, it is most certainly not beautiful." ${ }^{, 9}$ If interlingual translation undoubtedly involves something "missing" then the aim of the study reported in this paper is to minimize such missing things, as far as English thereconstructions and their Vietnamese counterparts are concerned. More specifically, this study aims to discuss there-constructions in the English language and to compare them with their Vietnamese counterparts in order to identify translated versions of each subtype of English thereconstructions. This comparison is considered to be important, given the fact that Vietnamese has neither the empty subject nor subject-verb inversion - the two phenomena quite easily observed in a Subject-prominent language ${ }^{10}$ like English.

To meet the above-mentioned aims, in addition to Introduction, Literature Review, Aims of the Study and Conclusion, this paper is structured into three main sections: English there-constructions, Counterparts of English thereconstructions in Vietnamese, and Discussion and Findings.

\section{English there-Constructions}

Some preliminary notes are necessary before the close look at different types of English there-constructions.

\subsection{Some Preliminary Notes}

\subsubsection{Adverbials vs. Adjectivals}

Stageberg and Oaks (2000) [4] distinguish adverbials from adjectivals. Adverbials [4: 263-269] are single words or word groups that occupy the adverb positions and perform the adverb functions. Common adverbial positions are:

Initial position:

Really, you should know better.

Now it is time to go.

Medial position:

Mary in her own way was a darling.

He is always/ at any event happy.

She would seldom make effort.

Final position:

He drove recklessly/ with abandon.

She is outside.

Hoskins will play football tomorrow.

Adjectivals [4: 259-263] are single words or word groups that occupy the adjective positions and perform the adjective functions. Adjectivals occupy certain characteristic sentence positions:

Between the determiner and the noun:

That joyfull college/ laughing/ recommended freshman is bright.

Right after the noun:

The fellow waving drives a convertible.

Right after an intensive verb:

\footnotetext{
${ }^{9}$ http://grammar.about.com/od/tz/g/translationterm.htm

${ }^{10}$ called "một ngôn ngữ thiên Chủ ngữ" in Vietnamese
}

He always remains quiet.

Right after the direct object of a complex transitive verb:

The management considered him competent.

Right before the noun:

Angry and upset, the applicant slammed the door.

\subsubsection{Locatives as One of the Two Most Common Type of Adverbials in English there-Constructions}

Locatives - the adverbials of place - constitute the most common types of adverbials in English there-constructions, as illustrated in the above-mentioned examples numbered (4), (7), (8), and (9). Below are two more; the former proves that an adverbial expansion with Locative there is quite accepted:

(14) There ' $\mathrm{S}$ a wheelbarrow down there. (Biber et al, 1999) [5]

(15) Under the desk there IS a woven wastepaper basket.

The second common type of adverbials in English thereconstructions is the temporal - the adverbials of time:

(16) There WASn't any rule against discrimination then .

(17) There WAS, once upon a time, another book from which this kind of scientific certainty was derived. (Longman Exams Dictionary, 2006) [6]

(18) There now FOLLOWS a party political broadcast. (Eastwood, 1994) [7]

"The adverbial is sometimes understood in the context: You know this party we're going to. Will there be any food (at the party)?" [7: 58]

\subsubsection{Distinction between Empty there and Locative there}

Empty there is not stressed and is often spoken in its weak form, like the. In other words, Empty there, which has no lexical meaning, is not the same as Locative there meaning "in that place." The adverbial is pronounced in its strong form, like their, with some identifiable stress:

(19) There WAS a van there, outside the house. [7]

Locative there is the antonym of the adverb here, meaning "in this place":

(20) "There' S a cat here under the casket," she called to her brother. [5]

\subsection{Bare Existential Sentences}

Sentences with there in the initial position, called English there-constructions in this paper, do not constitute a homogeneous class. For the sake of translation practice as well as adequate proof for the following discussion and findings, from this section each example in English is followed by its Vietnamese translation(s).

Frame 1: There + VERB + indefinite subject NP

Bare existential sentences, i.e. those in which the subject $\mathrm{NP}$, with or without postmodification, is not followed by any adverbial, are always themeless. The speaker has no other choice, except to choose a different verb, like exist in (24):

(21) There ARE no ghosts. Không CÓ ma.

(22) *No ghosts ARE. *Không ma CÓ. *Không ma THİ.

(23) *Ghosts ARE NOT. 


\author{
*Ma THÌ không. \\ (24) Ghosts DO NOT EXIST. \\ Không CÓ ma. \\ *Không TỒN TẠI ma. \\ ?Ma THİ không CÓ. \\ ?Ma THÌ không TỒN TẠI.
}

Generally, bare existential sentences assert the existence or non-existence of some entity with some property described by the modification of the subject NP, prenominal or postnominal. Being the focus, the subject NP has a higher degree of communicative dynamism (abbreviated to C.D.) than its preceding verb. Textually, (21) and (23) are not equivalent. In (24) the NP ghosts is anaphoric, probably mentioned in the context or co-situation; therefore, ghosts in (24) carries a lower C.D. degree than its following verb, i.e. it is not the focus of information conveyed by (24). Its verb is.

It is accepted for a bare existential sentence to be embedded in another clause:

(25) It sounds to me [as if there's a tap running somewhere].

Tôi nghe [như thể CÓ tiếng vòi nước chảy đâu đây].

"We can use there + be without an adverbial. This happens with nouns expressing a situation or event: I'm afraid there's a problem. (A problem exists.); There has been an accident. (An accident has happened.)" [7: 58]

"Minimal existential clauses, i.e. clauses which lacks both averbial expansions and subjects with postmodification, are most common in conversation..." [5: 949]

\subsection{True Existential Sentences}

It is the occurrence of the adverbial that distinguishes true existential sentences from bare existential sentences. Since "place adverbials are the most common type of adverbial expansion" [5: 949], the two subtypes of true-existential sentences respectively named Frame $2 a$ and Frame $2 b$ below are collectively called "locative-existential sentences" by Grzegorek [2: 149-154, 157-160].

"Final position for adverbials is by far the most common choice in clauses that have a notional subject without postmodification ... Where the notional subject has postmodification, preferences are less clear. Most often, however, the adverbial is placed towards the end of the clause, either in final position, or in initial-end position" [5: 949].

Frame 2a:

There + VERB + indefinite subject $\mathrm{NP}+\operatorname{adverbial}(s)$

Frame $2 b$ :

Adverbial $(s)+$ there + VERB + indefinite subject NP

True existential sentences in Frame $2 a$ and Frame $2 b$ present two problems:

1 What is the relationship between Frame $2 a$-true existential sentences and sentences in which the subject NP is in thematic position, i.e. what is the relationship of (26) and (27)?

(26) There'S a strange-looking woman in the house. CÓ một người phụ nữ lạ mặt ở trong nhà.

(27) A strange-looking woman IS in the house.
Một người phụ nữ lạ mặt THÌ ở trong nhà.

2 What is the relationship between Frame $2 b$-true existential sentences and sentences with a preposed locative adverbial without there, i.e. what is the relationship of (28) and (29)?

(28) In the house there'S a strange-looking woman.

Ở trong nhà CÓ một người phụ nữ lạ mặt.

(29) In the house IS a strange-looking woman.

Ở trong nhà LÀ một người phụ nữ lạ mặt.

In the same veins with Grzegorek [2], we argue here that the given example of Type a-sentences:

A strange looking woman IS in the house.

Indefinite $\mathrm{NP}-\mathrm{BE}$ - Locative

is not existential and hence is not cognitively synonymous to the given example of Frame $2 a$-true existential sentences:

There's a strange looking woman in the house.

There - BE - indefinite NP - Locative

because only the Frame $2 a$-true existential sentence asserts the existence of the referent of the NP, and in fact this assertion is the main purpose of uttering such sentences. In the Type $a$-sentence, the purpose of the speaker is to assert not the existence but the location of the referent of the NP.

Observed by Breivik [8], as quoted in Grzegorek [2: 150151], for Type a-sentences to be acceptable, there are two requirements:

- The locative adverbial must be [+ deictic], i.e. must refer to some well-defined, usually small area, known to the addressee: only then the spatial relationship between the referent of the subject and the location is clearly defined and hence the referent of the subject is identified. Since the requirement that the referent of the subject identified to the hearer does not hold ${ }^{11}$ in the case of Frame $2 a$-true existential sentences, they are acceptable in the following examples; Type $a$-sentences are not accepted because they fail to meet such requirement:

(30) a.*A book IS on the table.

*Một quyển sách THÌ ở trên bàn.

b. There IS a book on the table.

CÓ một quyển sách ở trên bàn.

(31) a.*A famous cathedral IS in Guildford.

*Một nhà thờ rất nổi tiếng THÌ $o$ Guildford.

b. There IS a famous cathedral in Guildford.

CÓ một nhà thờ rất nổi tiếng $o ̛$ Guildford.

(32) a. *Lions ARE in Africa.

?Sư tử THÌ ơ Châu Phi. ${ }^{12}$

b. There ARE lions in Africa.

CÓ sư tử ở Châu Phi.

- The NP subject must be capable of referential use, i.e. it must be specific rather abstract. There is no such condition for there-constructions:

\footnotetext{
${ }^{11}$ You do not have to identify the object if your purpose is merely to assert its existence.

${ }^{12}$ Quite probably, the generic state of the NP "sư tử, meaning "lions" (or "the lion"), in thematic position makes this Vietnamese version acceptable. For further information, read "Generic sentences in Vietnamese and English" (Thanh Minh To, 2011) [19].
} 
(33) a.* Space IS in the manger.

*Khoảng không THİ ở trong cái máng đựng thức ăn cho gia súc.

b. Corn IS in the manger.

Bắp THÌ ở trong cái máng đựng thức ăn cho gia súc.

(34) a. There IS space IS in the manger.

CÓ khoảng không ở trong cái máng đựng thức ăn cho gia súc.

b. There IS corn in the manger.

CÓ bắp ở trong cái máng đựng thức ăn cho gia súc.

(35) a.*Nothing IS in the house.

* Không cái gì THİ ở trong căn nhà này.

b.*No sign of life IS in the house.

*Không dấu hiệu của sự sống nào THÌ ở trong căn nhà này.

(36) a. There IS nothing in the house.

Không CÓ cái gì ở trong căn nhà này.

b. There IS no sign of life in the house.

Không CÓ dấu hiệu của sự sống nào ở trong căn nhà này.

Only there-constructions, the subject NP of which is postmodified by a participial phrase, always have accepted counterparts with indefinite NPs in thematic position. These counterparts cannot be considered as existential, though:

(37) a. A demonstrator WAS KILLED by a policeman in Oakland.

Một người tham gia biểu tình đã $B I$ cảnh sát GIẾT CHÊT ở Oakland.

b. There WAS a demonstrator KILLED by a policeman in Oakland.

Đã CÓ một người tham gia biểu tình $B I$ cảnh sát GIẾT CHỂT ở Oakland.

(38) a. A girl IS PLAYING in the roof of your house.

Một bé gái đang CHÖI trên mái nhà của anh.

b. There IS a girl PLAYING on the roof of your house.

CÓ một bé gái đang CHƠI trên mái nhà của anh.

The relationship of Type $b$-sentences, those with $a$ preposed locative adverbial without there, and Frame $2 b$-true existential sentences is not clear. With the same reason concerning Type a-sentences, we again argue that the given example of Type $b$-sentences:

On the table WAS a book.

Locative - BE - indefinite NP

is not existential and hence is not cognitively synonymous to the given example of Frame $2 b$-true existential sentences:

On the table there WAS a book.

Locative - there - BE - indefinite NP

Observed by Breivik [8], as quoted in Grzegorek [2: 153154], for Type $b$-sentences, which are inverted sentences, to be accepted, there is one requirement: Locative must be specific enough:

(39) *In the house WAS no sign of life.

*Trong căn nhà LÀ không dấu hiệu nào của sự sống.

(40) *In Africa ARE lions.
* Ở Châu Phi LÀ sư tử.

(41) Under the desk IS a woven wastepaper basket.

Duói cái gầm bàn ấy LÀ một cái giỏ rác đan bằng mây tre.

(42) To the east of the pier WERE miles of sandy beaches.

Về phía đông của cái cầu tàu LÀ những bãi cát dài hàng dặm.

Quite probably, Locative is made specific by the preceding sentence of Type $b$-sentences, not by themselves [9:220]:

(43) Alan walked along Elmdate Avenue and found number sixteen without difficulty.

Outside the house WAS a furniture van. [7]

Alan đi bộ dọc theo Đại lộ Elmdate và tìm ra căn nhà số 16 không khó khăn gì.

Bên ngoài căn nhà ấy CÓ một chiếc xe chở hàng nội thất.

(44) The room contains a table and four chairs. On the table LAY a newspaper. [7]

Căn phòng có một cái bàn và bốn cái ghế. NẰM trên bàn LÀ một tờ báo.

In brief, not considered as existential are Type a-sentences and Type $b$-sentences, with (i) the indefinite NP playing the semantic role of Carrier (called Duong thể in Vietnamese [9: 136-143, 214-217]) and (ii) the verb be translated into Vietnamese typically as $l \grave{a}$, as in the Vietnamese version of (41) and (42), when Locative preceding the indefinite NP in Type bsentences; or optionally as thì as in (33)b, when Locative following the indefinite NP in Type $a$-sentences. True existential sentences in Frame $2 a$ and Frame $2 b$ are "variants of the same existential proposition" [2: 154], with (i) the indefinite NP playing the semantic role of Existent (called Hĩu thể in Vietnamese [9: 157-158]) and (ii) the verb be or verbs other than $b e$ but of related meaning typically translated into Vietnamese as có:

There WAS a book on the table.

There - BE - indefinite NP - Locative (Frame 2a)

On the table there WAS a book.

Locative - there - BE - indefinite NP (Frame $2 b$ )

In comparison to Frame $2 a$-true existential sentences, Frame $2 b$-true existential sentences are more marked because the S-V-O order of English clauses does not treat the adverbial in the left-most position as normal; on the contrary, Type $a$-sentences, with a number of strict restrictions presented previously in the paper, are much less common and thus far more marked than Type $b$-sentences, those quite often being employed rhetorically in academic writing.

Though Locative and Temporal form the two most common types of adverbials in Frame $2 b$-true existential sentences, others are adverbials of condition, as in (45), and of cause or reason, as in (46):

(45) If the police hadn't reacted quickly, there COULD HAVE BEEN a bad accident.

Nếu cảnh sát không phản ứng kịp thờ thì có thể đã CÓ một tai nạn thảm khốc.

(46) Because natural gas is an environmentally clean fuel, there IS great interest on the part of many scientists 
and policy makers to assess its availability. [5]

Do khí thiên nhiên là một thứ nhiên liệu sạch xét tù̀ góc độ môi truờng nên CÓ sự quan tâm lớn từ nhiều nhà khoa học và chuyên gia hoạch định chính sách nhằm đánh giá trữ lượng của nó.

Frame 2a-true existential sentences are used "when we want to:

- announce or report events: There'll a meeting tomorrow;

- set a scene for story-telling: There had been no rain for months. The earth was bare." (Alexander, 1990: 146) [10]

Frame $2 b$-true existential sentences can be easily identified thanks to the tag question though there may be optionally omitted from the clause preceding the tag:

(47) On the wall (there) IS a Picasso painting, isn't there? Trên tuờng CÓ một bức tranh của Picasso, phải không?

(48) All around (there) WAS a thick hedge, wasn't there? Xung quanh CÓ một bụi cây rậm rạp, phải không?

However complex it is, a true existential sentence can easily play the role of an embedded clause, as in (49).

(49) It is obvious [that in my first poems there EXISTS kind-heartedness of a young man who has learned to love the poor and the miserable]. [9]

Rõ ràng [là trong tho tôi buổi đầu CÓ tấm lòng của con người trẻ tuổi biết yêu thương những thân phận nghèo khổ đoạ đày].

\subsection{There-Constructions as 'Lists'}

Frame 3:

$($ Adverbial +$)$ there + VERB + definite/indefinite subject NP

"On context where it is appropriate to focus on the existence of something is at the beginning of a story. The fairly-tale opening is well-known" [5: 951]:

(50) Once upon a time there WAS a wicked step-mother.

Ngày xủa ngày xua CÓ một bà mẹ kế độc ác.

In there-constructions as 'lists', the subject NP can be either indefinite or definite. When the subject NP is definite, i.e. encoded by a definite noun phrase or a proper noun, the effect of Empty there is "to bring something already known back to mind rather than asserting that it exists" [5: 953]. Below are two other examples with there-constructions as 'lists' being part of the dialogues given by Grzegorek [2]:

Dialogue 1 A: How could we get there? Làm sao bọn mình đến đó?

B: There 'S the trolley ... CÓ xe điện ...

Dialogue 2 C: What's worth visiting here? Có gì đáng tham quan nơi đây?

D: There 'S the park, a very nice restaurant, and the library.

CÓ công viên, một nhà hàng rất đẹp, và thư viện.

Even if the subject NP is definite, still the general condition of there-constructions is met because this NP is non-anaphoric. Rando and Napoli (1978: 300) [11], as quoted in Grzegorek [2: 154], explain this fact as follows:

'Existential' there-sentences typically allow only indefinite
NP arrangements, while 'list' there-sentences accept both definites and indefinites. The reason for this difference is that the argument of an existential there-sentence is the NP itself; but the argument of a list there-sentence is the list, not the individual members comprising that list.

In other words, it is the list, i.e. the choice of the items, is the new information irrespective of the fact that all the items of the list are anaphoric. It is acceptable that the list consists of only one member, as in There ' $S$ the trolley ..., because "list there-sentences do not assert existence. They can be paraphrased as 'one could mention ...' i.e. only bring the referent of the focus NP to the addressee's consciousness" [2: $154]^{13}$.

The term "list" is quite useful in describing as well as distinguishing there-constructions as 'lists' from 'true' existential there-sentences. Biber et al [5: 947] also imply such a list: "Existential there-constructions with a definite notional subject tend to occur when a series of elements is introduced, often marked explicitly by a conjunction or a linking adverbial (e.g. first) or additive adverbial (e.g. too)."

(51) There'S Raymond and his wife and his wife Sherry's, I think, brother and his wife. [5]

CÓ Raymond và vợ của ông, và tôi nghĩ rằng, người anh em trai của vợ ông và vợ của anh ấy.

(52) First there 'S the scandal of Fergie romping with John Bryan. [5]

Trước hết CÓ tai tiếng rằng Fergie tằng tịu với John Bryan.

The definite subject NP may contain the demonstrative determiner this or these, "often found in joke-telling" [5: 947].

(53) Dad, there WAS this alien. He had enormous hands and silver eyes and he was really ugly. [5]

$\mathrm{Ba}$ à, CÓ người ngoài hành tinh này nè. Hắn có đôi tay to, đôi mắt màu bạc và trông hắn thì thật là xấu xí.

"The notional subject is occasionally a definite noun phrase or a proper noun. Examples are found in all registers ... these constructions occur primarily in conversation (about 50 instances per millions of words) and occasionally in fiction" [5: 947].

\subsection{Presentational There-Constructions}

Frame 4a:

There + VERB + adverbial + indefinite subject NP

(54) There LIVES next door to me a blind woman. Cạnh nhà tôi SỐNG LẬNG LẼ một người phụ nữ mù.

SỐNG LẶNG LẼ ${ }^{14}$ cạnh nhà tôi LÀ một người phụ nữ mù.

(55) There FOLLOWED after weeks of intense fighting a

\footnotetext{
${ }^{13}$ Eastwood [7: 58] similarly states that the referent of the focus NP can be something specific: "We can use the in this pattern when we remind someone of the existence of something specific: What can I stand on to reach that bulb? Well, there's the stepladder."

${ }^{14}$ In this example, the verb sống, which means "lives", cannot occur alone but must be accompanied by the adverb of manner lạng lẽe, which means "silently."
} 
Frame 4b:

brief period of calm.

Sau nhiều tuần giao tranh ác liệt LÀ một khoảnh khắc yên bình.

Adverbial + there + VERB + indefinite subject NP

(56) On top of the hill there STANDS an ancient church tower. [7]

Trên đỉnh đồi ĐỨNG SỪNG SỨNG một tháp chuông nhà thờ cổ.

SỨNG SỨNG ${ }^{15}$ trên đỉnh đồi LÀ một tháp chuông nhà thờ cổ.

(57) On the wall there HANGS a landscape.

Trên tuờng TREO một bức tranh phong cảnh.

TREO trên tuoơng LÀ một bức tranh phong cảnh.

This type of there-constructions can also be identified thanks to the tag question though there may be optionally omitted from the clause preceding the tag:

(58) On the wall HANGS a landscape, doesn't there?

Trên tuoòng TREO một bức tranh phong cảnh, phải không?

The choice between the presentational there-construction (59), which is non-thematic, and its thematic counterpart (60) depends typically on the way the speaker wants to present things: the referent of the subject NP seen from the speaker's view as "coming into the perceptual field of the speaker," Kimball (1973: 265) [12], as quoted in Grzegorek [2: 154]:

(59) There STEPPED OUT in front of the car a little girl. [2] Ngay trước mũi xe BƯỚC RA một cô bé. BƯỚC RA ngay truớc mũi xe một cô bé.

(60) A little girl STEPPED OUT in front of the car. Một cô bé BƯớC RA ngay truớc mũi xe.

"A little girl is the last element in the picture perceived by the speaker. It could not be put in the thematic position because it was not 'available' when the speaker starts his message." [2: 155] That's why (59) is preferred to (60). That's also why only a specific group of verbs allows the presentational orders: active verbs indicating the appearance on the scene such as run out, burst in, step in, etc. and stative verbs describing location such as hang, lie, sit, stand, live, etc. Also it is clear why (61) is preferred to (62):

(61)All of a sudden there BURST IN his younger sister Jane. [2]

Đột nhiên/ Bất thình lình em gái của anh, Jane, XÔNG VÀO.

?Đột nhiên/ Bất thình lình XÔNG VÀO em gái của anh, Jane.

(62) His younger sister Jane BURST IN all of a sudden.

Đột nhiên/ Bất thình lình em gái của anh, Jane, XÔNG VÀO.

?Em gái của anh, Jane, đột nhiên/ bất thình lình XÔNG VÀO.

*Em gái của anh, Jane, XÔNG VÀO đột nhiên/ bất thình lình.

\footnotetext{
${ }^{15}$ The fact that the verb díng, which means "stand", cannot occur alone and that the adverb of manner sùng süng, which means "bulkily", can temporarily replace the verb díng, proves how important the adverb is to make the meaning of the Vietnamese sentence in question complete. This requires further consideration which is in fact out of the scope of the very paper.
}

\section{Counterparts of English There-Constructions in Vietnamese}

\subsection{Some Preliminary Notes}

There-constructions constitute the third type [9: 217-223] of subject-verb inversion or full inversion ${ }^{16}$ - "where the subject is preceded by the entire verb phrase" [5: 911]. This phenomenon is easily observed in English, as mentioned by Eastwood [7: 55]:

The subject often comes at the beginning of a statement, but not always. We sometimes put another phrase in front position before the subject. We do this to emphasize the phrase or to contrast it with phrases in another sentence. The phrase in front position is more prominent than in its normal position.

- The empty subject ${ }^{17}$

To obey the basic word order of English sentences, which is $\mathrm{SV}(\mathrm{O})$, Empty there - a lexically empty formative functioning as a slot filler - is introduced in thereconstructions. While no English there-constructions begin with a finite verb, their Vietnamese counterparts may: the Vietnamese verb is shifted to the initial position and no slot filler is necessary; in other words, there is no empty subject in Vietnamese in any counterpart of any type of English there-constructions quite probably because (i) $\mathrm{SV}(\mathrm{O})$ is not the basic word order in Vietnamese and (ii) the function of word order in English is to signal syntactic functions of lexical items while in Vietnamese to signal the communicative function of the lexical items (old versus new information).

In the beginning, Vietnamese learners of English may find it uneasy to deal with Empty there because they are not used to the fact that "in a Subject-prominent language a subject may be needed whether nor not it plays a semantic role" ( $\mathrm{Li}$ and Thompson, 1976: 467) [13].

Also, Vietnamese learners of English may find it even more difficult to distinguish Empty there in various types of there-constructions that have been discussed up to now in this paper from Locative there in what Biber et al [5: 954956] call "Locative inversion," which looks just like what we name in this paper Type $b$-sentences, as in (63-65):

(63) There's my father.

Kia LÀ cha của tôi.

(64) There GOES William! Kìa, William ĐI ở đằng kia!

(65) Behind the sundial there WERE a few trees, some of them in flower: a small path led into their deceptive shallow depths, and [there, in a hollow a few yards from a high brick wall that bordered the garden, STOOD a sculpture]. [5]

Đằng sau cái đồng hồ mặt trời CÓ dăm ba cây xanh, một số đang trổ hoa: một con đường mòn dẫn đến

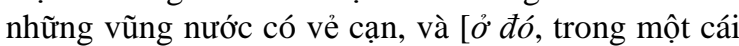
hố cách vài mét là đến bờ tường cao xây bằng gạch

\footnotetext{
${ }^{16}$ called "cấu trúc đảo" in Vietnamese

${ }^{17}$ called "chủ ngữ rỗng (nghĩa)" or "chủ ngữ giả" in Vietnamese
} 
bao bọc khu vườn, ĐỨNG SỪNG SỨNG một tác phẩm điêu khắc].

Unlike Empty there, Locative there, enclosed in the square brackets in the English sentence numbered $(65)^{18}$, must be spoken with stress, as previously mentioned.

- The definiteness of the English subject NP in 'list' there-constructions

There are two rules concerning the statement that definiteness and Topic status of the Subject will very often coincide (Dik, 1978) [14]: backshifting indefinite subjects, as in the above-mentioned (30)b, and fronting definite subjects, as in the following $(30) \mathrm{c}$ :

(30)c. The book IS on the table. Quyển sách đó thì ở trên bàn.

(30)d.*There IS the book on the table. ?CÓ quyển sách đó ở trên bàn.

- The word order in there-constructions

The verb precedes the NP in both English thereconstructions and their Vietnamese counterparts. This follows the principle of arranging lexical items according to the increasing C.D. degree. This order is unmarked in the two languages: it is not motivated by contextual factors but rather by the inherent semantic feature of verbs of being - those that always have a lower C.D. degree than any noun accompanying them.

\subsection{Counterparts of Bare Existential Sentences ${ }^{19}$}

English: There + VERB + NP

Vietnamese: VERB + NP

The most common existential verb in Vietnamese is có; next comes còn (lai). It is worth noticing that no signal of the simple past of be in (67)a is necessary because it is already conveyed in that of was killed, resulting in đã bi giết; this partly helps to prove that redundancy is not characteristic of the Vietnamese language:

(66) a. There'S a gentleman in black waiting outside.

b. CÓ một quí ông mặc toàn đồ đen đang đợi (ở) bên ngoài.

(67) a. There WAS a rumor that the president was killed. b. CÓ tin đồn rằng tổng thống đã bị giết.

The negative form of có is không có, không còn, or hết. Again, no signal of the simple past of be in (68)a is necessary because the Vietnamese word $đ \tilde{a}$ refers to the perfect aspect rather than the past tense; native speakers of Vietnamese identify the simple past via some clue from context instead of verb conjugation. And the combination of 's, no and left in (69)a and that of remains and no in (70)a both result in không còn or hết; while không có in (68)b is equivalent to was no. This indicates that no word-by-word translation is treated as appropriate, irrespective of our effort to present the meaning of

\footnotetext{
${ }^{18}$ i.e. [there, in a hollow a few yards from a high brick wall that bordered the garden, STOOD a sculpture]

${ }^{19}$ For direct naming and thus quicker retrieving, it is necessary to confirm one more convention applied in this paper from now on, in addition to the other five presented right at the beginning of the paper: each of the original English constructions selected as illustrations is numbered, marked $a$ and followed its the Vietnamese translated version(s), marked either $b$, or both $b$ and $c$, etc.
}

individual words, if possible.

(68) a. There WAS nobody.

b. Không CÓ ai.

(69) a. There 'S no money left.

b. Không CÒN tiền.

c. HÊT tiền.

(70) a. There REMAINS nothing more to be done.

b. Không CÒN cái gì để làm nữa.

c. ?HÊT việc.

The fact that the sentence $(71) \mathrm{c}^{20}$ is typically found in a Topic-prominent language ${ }^{21}$ like Vietnamese illustrates another way to express the meaning conveyed by (71)a. Most less accepted is (71)d the word order of which strictly follows that of (71)a - the original English sentence.

(71) a. There ARE only a few pieces of candy left.

b. Chỉ CÒN (LẠI) mấy cái kẹo thôi.

c. Kẹo chỉ CÒN (LẠI) mấy cái/ mấy chiếc thôi.

d.?Chỉ CÓ vài cái kẹo còn để lại/ được để lại.

Together with (71)a-d, (72)a-c again help to prove that word-by-word translation fails.

(72)a. There'S nothing wrong with your car.

b. Cái xe của anh CÓ làm sao đâu.

c. Cái xe của anh không (bị làm) sao hết.

\subsection{Counterparts of Frame 2a-True Existential Sentences}

$$
\begin{aligned}
& \text { English: There + VERB + NP + adverbial }(s) \\
& \text { Vietnamese: EE adverbial }(s)+\text { VERB + NP } \\
& \text { VERB + NP + adverbial }(s)
\end{aligned}
$$

The grammatical properties of the Equivalent to the English adverbial $^{22}$ commonly placed at the beginning of the Vietnamese clause, which is abbreviated to EE adverbial, makes this case definitely unmarked; therefore, "during the process of English-Vietnamese translation, the adverbial of time is almost obligatorily fronted usually from the end of an English clause to the beginning of its Vietnamese version, following the Topic-Comment structure prominently observed in the Vietnamese clause. Such fronting is not obligatory but optional in a number of cases:

- When the translated version has its final adverbial of time in the form of not an NP but a PP so that the principle of end-weight ${ }^{23}$ may be obeyed strictly;

- When there exists a final sequence of an adverbial of space before an adverbial of time, which is quite common in the two languages in question;

- When the English clause has its final adverbial of time referring to extent in time." (Thanh Minh To, 2014: 353) [15]

(73) a. There HAVE BEEN several break-ins this year. b. Năm nay đã CÓ nhiều vụ đột nhập giữa ban ngày. d. Trong năm nay đã CÓ nhiều vụ đột nhập giữa ban

\footnotetext{
${ }^{20}$ A stricter English version of which is the following (71)c':

(71)c'. As for candy, there ARE only a few pieces left.

${ }^{21}$ called "một ngôn ngữ thiên Chủ đề" in Vietnamese

${ }^{22}$ For further information, read "The English adverbial of time vs. The Vietnamese range topic of time" [15].

${ }^{23}$ "the tendency for long and complex elements to be placed towards the end of a clause" [5: 898]
} 
ngày.

c.*Đã CÓ nhiều vụ đột nhập giữa ban ngày năm nay. d.?Đã CÓ nhiều vụ đột nhập giữa ban ngày trong năm nay.

(74) a. There WERE several people sick after the party. b. Sau bũa tiệc CÓ nhiều người bị bệnh/ đổ bệnh. c. *CÓ nhiều người bị bệnh/ đổ bệnh sau bũa tiệc.

(75) a. There IS snow on high ground every winter. b. Mỗi mùa đông đều CÓ tuyết trên vùng cao. c. Trên vùng cao đều CÓ tuyết mối mùa đông.

d. CÓ tuyết trên vùng cao mối mùa đông.

e. Mùa đông nào cũng Có tuyết trên vùng cao.

Fronting is also recommended in the case of the final adverbial of space as in (76-77)a. The combination of $i$ and still in (77)a result in vẫn còn, while còn is the Vietnamese equivalent of exists in (78)a whose Vietnamese version, which is (78)b, is its thematic variant; like (71)c, (72)b-c, (75)e, and (77)d-e:

(76) a. There WAS no beer left in the fridge.

b. Trong tủ lạnh không CÒN bia.

c. Không CÒN bia trong tủ lạh.

(77) a. There IS still some money in the pocket.

b. Trong túi vẫn CÒN tiền.

c. Vẫn CÒN tiền trong túi.

d. Túi vẫn CÒN tiền.

e.?Túi đang CÒN một số tiền. (Vietnam Committee of Social Sciences, 1983) [16]

(78) a. There EXISTS a king in Sweden.

b. Thụy Điển CÒN vua.

Since there is no verb conjugation in Vietnamese, the simple past, which is a grammatical means in English, is replaced by the Vietnamese lexical item lúc ấy meaning "at that time":

(79) a. There WAS nobody home.

b. Lúc ấy không CÓ ai ở nhà.

c. Lúc ấy ở nhà không CÓ ai.

d. Không CÓ ai ở nhà lúc ấy.

e.*Không CÓ ai lúc ấy ở nhà.

f.*Ở nhà lúc ấy không CÓ ai.

The optional fronting of the final adverbial of space during the Vietnamese-English process of translation holds true even when the Vietnamese equivalent version of (80)a, which is (80)b, is only an embedded clause.

(80)a. There IS SAID TO BE a mismatch between the mother tongue and the target language at these points.

b. Người ta NÓI [rằng ở nhũng điểm này CÓ một sự thiếu tương xứng giữa tiếng mẹ đẻ và ngôn ngũ đích].

c. Người ta NÓI [rằng CÓ một sự thiếu tương xứng giữa tiếng mẹ đẻ và ngôn ngữ đích $o^{3}$ nhũng điểm này].

\subsection{Counterparts of Frame 2b-True Existential Sentences}

English: Adverbial + there + VERB + NP

Vietnamese: EE adverbial + VERB + NP

The adverbial is usually at the end of the English clause; however, clause initial placement is also possible.

(81)a. Near the park there WERE no more trees, just rock and grass. [5]

b. Gần công viên không CÒN cây nữa, chỉ toàn là đá và cỏ.

(82)a. Inside the hall there WAS PILED a large assortment of packages and parcels and small articles of furniture. On every item there WAS a label tied. [5]

b. Bên trong cái hành lang CÓ một đống lớn gồm các thùng và gói hàng và đồ dùng trong nhà thuộc loại nhỏ. Trên tù̀ng mối thứ CÓ một cái nhãn được cột vào.

The ordering is conditioned by the same factors that affect the placement of time and place adverbials in general. In (8182)a, which are two fiction examples, the adverbial are tied to the preceding text and the clause ends with the indefinite NP, which contains new information. The ordering is therefore in agreement with the information principle.

\subsection{Counterparts of There-Constructions as 'Lists'}

English: $($ Adverbial +$)$ there $+\mathrm{VERB}+\mathrm{NP}$

Vietnamese: (EE adverbial +) VERB + NP

(83) a. Once upon a time there WERE three bears: Mama bear, Papa bear and Baby bear. [5]

b. Ngày xưa ngày xưa CÓ ba con gấu: Gấu mẹ, Gấu cha và Gấu con.

(84)a. There IS also the group of non-benzenoid aromatic compounds. [5]

b. Cũng CÓ hỗn hợp gồm nhiều hợp chất không chứa benzene và có mùi thơm đặc trưng.

(85) a. There 'S the school bell - I must go now.

b. CÓ chuông trường rồi - bây giờ tôi phải đi đây.

It seems like no adverbial is needed sentence-initially when the NP is encoded by a definite noun phrase; as previously mentioned, the effect of Empty there in this case is just to bring something already known back to the addressee's mind, not asserting that it exists.

\subsection{Counterparts of Presentational There-Constructions}

- With a stative verb describing location such as lie, hang, sit, stand, etc.:

English: There + VERB + adverbial + NP

Vietnamese: EE adverbial + VERB + NP

$$
\mathrm{VERB}+\text { adverbial + LÀ + NP }
$$

(86)a. There HANGS on the wall a picture of the President.

b. Trên tuờng TREO một bức tranh của Tổng thống. c. TREO trên tuờng LÀ một bức tranh của Tổng thống.

(87) a. There STAND in the corner of the room a file cabinet.

b. Trong góc phòng ĐÚNG VUÔNG VẮN ${ }^{24}$ một cái

\footnotetext{
${ }^{24}$ In this example, the verb đíng, which means "stand," cannot occur alone but must be accompanied by the adverb vuông vắn, which means "neatly" or "tidily." Also see the above-mentioned sentences numbered (54).
} 
tủ đựng hồ sơ.

c. ĐỨNG VUÔNG VẮN trong góc phòng LÀ một cái tủ đựng hồ sơ.

It deserves noticing the second translated version of each of the examples given above in which là is placed right before the NP as a "pure" Vietnamese expression.

- With an active verb of directional movement such as burst in, jump out, step out, run through, walk into, enter, etc. or a stative verb denoting existence or occurrence such as appear, arise, come, emerge, exist, develop, follow, live, loom, remain, occur, etc.:

English: There + VERB + adverbial + NP

Vietnamese: EE adverbial + VERB + NP

$$
\text { VERB + adverbial + NP }
$$

(88)a. There OCCURRED ${ }^{25}$ the next day a strange incident. [7]

b. Ngày hôm sau đã XẢY RA một việc lạ lùng.

c. Đã XẢY RA trong ngày hôm sau một việc lạ lùng.

(89)a. There EXISTS in all such relations a set of mutual obligations. [5]

b. Trong tất cả các mối quan hệ nhu vậy TỒN TẠI một loạt những trách nhiệm qua lại.

c. Vẫn TỒN TẠI trong tất cả các mối quan hệ nhu vậy một loạt những trách nhiệm qua lại.

To deal with presentational there-constructions beginning with an adverbial, i.e. those following Frame 4b, apply "Tip 2: Do not change the Topic-Comment structure when translating from English to Vietnamese, if there is no compelling reason." [15: 353]

The pre-verbal adverb of time once is shifted to the leftmost position in $(90) \mathrm{b}$, filling the slot of the first adverbial; next comes Locative. This obeys the preferred order of a successive of two EE adverbials sentence-initially in the Vietnamese clause: time - space, following "Tip 1: Apply frequently in the Vietnamese clause the range topic of time as well as the double topic ${ }^{26}$, the first member being time; pay attention to the Vietnamese final sequence of two adverbials, the last member being time." [15: 353]

(90) a. In a small town in Germany there once LIVED a rich merchant who had a beautiful daughter.

b. Thuở xua trong môt thi trấn nhỏ ở nuơóc Đức CÓ một thương gia giàu có sống với cô con gái xinh đẹp. c. *Trong một thi trấn nhỏ ở nước Đức thuở xua CÓ một thương gia giàu có sống với cô con gái xinh đẹp.

The double topic time - space can also observed in (91)b one of the two translated versions recommended for (91)a:

(91) a. Then there RAN out of the bushes a grizzly bear. b. Rồi thì tù trong bụi rậm CHẠY RA một con gấu

\footnotetext{
${ }^{25}$ Which verbs other than be can occur in English existential sentences cannot be determined on a purely semantic basis. The matter remains a mystery. There is no explanation why begin can occur in there-constructions and its synonymy start is less acceptable [2: 167]:

There BEGAN a riot.

?? There STARTED a riot.

The same phenomenon can be observed between the two so-called synonyms occur and happen:

(88)a'. ??There HAPPENED the next day a strange incident

${ }^{26}$ which is called "đề kép" in Vietnamese
}

to lớn và hung dữ.

c. Rồi thì CHẠY RA tì̀ trong bụi rậm một con gấu to lớn và hung dữ.

In addition to Locative in (90)a and Temporal in (91)a, an adverbial of manner is clearly seen sentence-initially in (92)a as well as in the above-mentioned (61):

(92)a. Suddenly there ENTERED a strange figure dressed all in black.

b. Bỗng BUOỚC VÀO một người lạ mặt mặc toàn đồ đen.

This is true even when Locative already exists in a presentational there-construction like (93)a:

(93) a. Suddenly there JUMPED out of the hole a rabbit. b. Tù̀ trong cái lỗ bỗng NHẢY RA một con thỏ.

c. Bỗng NHẢY RA tù trong cái lỗ một con thỏ.

The adverb chơt, which also means "suddenly", almost obligatorily occurs in the translated version (94)c, to make it sound more like Vietnamese, even when the original English sentence (94)a does not actually include it:

(94)a. There AROSE somewhere deep inside her a desperate hope that he would embrace her. b. Ở đâu đó sâu thẳm trong cô TRỔI DẬY một niềm hy vọng mong manh rằng anh ấy sẽ ôm ghì lấy cô. c. Chợt TRỔI DẬY ở đâu đó trong sâu thẳm lòng cô một niềm hy vọng mong manh rằng anh ấy sẽ ôm ghì lấy cô.

\section{Discussion and Findings}

- English constructions with Empty there and their Vietnamese counterparts indicate the existence or occurrence of something (including the non-existence or non-occurrence of something). The use of Empty there in there-constructions "is in agreement with the information principle, as it serves to delay, and prepared the ground for, new information later in the clause" [5: 951]. Also, there is to bring something already known back to mind, rather than asserting that it exists. This is the case of there-constructions as 'lists' in which definite subject NPs may be employed to refer to known entities or phenomena, whose existence is not at issue.

- Their sound forms may help to distinguish Empty there from Locative there, the latter being stressed and frequently used as an adverbial in presentational thereconstructions. Below are examples given by Thomson and Martinet [17: 120]:

(95) a. There'S a man I want to see. (He is standing by the door.)

b. Kia LÀ một người đàn ông mà tôi muốn gặp. (Anh ấy đang đứng gần cánh cửa.)

(96) a. There'S a man I want to see. (This man exists.) b. CÓ một người đàn ông mà tôi muốn gặp. (Anh ấy tồn tại.)

We also find another pair of there-constructions that appropriately tells a presentational thereconstruction like (97)a from a Frame $2 a$-true 
existential sentence like (98)a:

(97) a. There'S my father.

b. Kia LÀ cha của tôi.

(98) a. There'S your father on the phone.

b. CÓ cha của chị (đang chò để nói chuyện) trên điện thoại.

Such a distinction is a bit harder but necessary within one and the same sentence, given as example by Murphy [18: 166]:

(99)a. When we arrived at the party, there WERE already a lot of people there (= at the party).

b. Khi chúng tôi đến bữa tiệc, đã CÓ nhiều người $o$. đó (= ở tại bũa tiẹc).

- As far as the adverbial in there-constructions is concerned, "in English a contextually bound locative phrase may occur in the clause initial position (marked construction) or in the clause final position (neutral word order)" [2: 159]. In Vietnamese, the adverbial in true existential sentences occurs almost always in the initial position as the range topic: more frequently of time and/ or of space and less frequently of condition, of cause (or reason), or of manner. When there is the double topic in Vietnamese translated versions, the first member should be time; in case of a sequence of two final adverbials in the Vietnamese clause, the last member should be time.

- The most common verbs in Vietnamese existential sentences are CÓ, CÒN, HẾT and their elaborate variants such as hiện CÓ, đã CÓ, không CÓ, thật ra là CÓ, hiện CÒN, vẫn CÒN, đang CÒN, không CÒN, CÒN LẠI, đã HÊT, etc. Roughly speaking, these are the Vietnamese equivalents of various affirmative and negative forms the English verb be conjugated in a number of different tenses. Among others are:

(i) Verbs other than be but of the related meaning of existence or occurrence: CÒN (remain), XUÂT HIỆN or HIỆN RA (occur, appear, arise, come, loom or emerge), TỒN TẠI (exist), PHÁT TRIÊN (develop or grow), TIÊP THEO (follow), SỐNG (live), etc.

(ii) Active verbs temporarily used as stative verbs describing location: ĐÚ'NG (stand), NGỒI (sit), NẰM (lie), ĐU (hang), TREO (hang), etc.;

(iii) Active verbs of directional movement: BƯỚC VÀO (step in, walk into, or enter), XÔNG VÀO (burst in), BUỚC RA (step out), etc.

- It is not only the lexical meaning of the English verbs but also the syntactic meaning of the whole clause in question that sometimes determines a more appropriate equivalent translated version in Vietnamese: follow means tiếp theo LÀ in (100)b; the verb is simply translated as LÀ in (101)b. This partially proves that word-by-word translation is in danger of being a complete failure in the case of English thereconstructions:

(100)a. There FOLLOWED an uncomfortable silence.

b. Tiếp theo LÀ một sự im lặng không mấy dễ chịu.

(101)a. After weeks of intense fighting there FOLLOWED a brief period of calm.

b. Sau nhiều tuần giao tranh ác liệt LÀ một khoảnh khắc bình yên.

- Though there exists the distinction between definiteness and indefiniteness applied to the NP in English thereconstructions and their Vietnamese counterparts, ways to indicate such a distinction are unfortunately not the same, considering as an example the fact that the zero article $^{27}$ is [+definite, +singular] in Vietnamese [19: 28, 33 , as in (102)b, while it is [-definite, +plural] in English, as in (102)a.

(102)a. There ARE lions in Africa.

b. CÓ sư tử ở Châu Phi.

c. *CÓ những con sư tử ở Châu Phi.

- Not much has been done to discuss explicitly the role of the adjectival in the English subject NP; but this does not mean that it has been ignored. Instead, its significance is gradually exposed via hundreds of translated versions in Vietnamese employed as illustrations in the paper. The very role deserves further consideration which is out of the scope of this paper.

- Presentational there-constructions are characteristic of having their thematic counterparts and employing only two subtypes of verbs: active verbs of directional movement and stative verbs describing location. The group of verbs other than be denoting existence or occurrence is the overlap, as far as the employment of the verb is concerned, between presentational thereconstructions and various types of existential sentences in English. Undoubtedly, be is the "privilege" of English existential sentences, both bare and true, just like $c o$ in their Vietnamese counterparts. The vital role of be in English there-constructions is undeniable, seemingly simple but in fact too complicated for generations of learners of the English language, both native and non-native, to toss and turn.

\section{Conclusion}

Breakdowns in communication in any way, either by accident or on purpose, are somewhat odd. Any efforts to avoid such breakdowns is worth trying in our changing world. Interlingual translation has been contributing to these efforts: results of researches in linguistics are continually applied to translation practice, as far English and Vietnamese are concerned, as well as to teaching and learning the two natural languages. Hopefully, a correct type of English thereconstructions is used to translate "LỜ MỜ HIỆN RA tù trong làn sưong mỏng một dáng hình kỳ lạ" to "Out of the mist there LOOMED a strange figure." And the two following Vietnamese versions can be identified for (103)a.

(103)a. There ROSE to her lips always some exclamation of triumph over life. [5]

b. Luôn TRÀO DÂNG lên đầu môil ra cưa miệng của cô những cảm nhận về thành tựu trong cuộc

\footnotetext{
${ }^{27}$ i.e. the absence of any article, which called "quán từ zero" in Vietnamese
} 
sống.

c. Ở đầu môi/ cửa miệng của cô luôn LÀ những cảm nhận về thành tựu trong cuộc sống.

\section{References}

[1] Halliday, M. A. K., An Introduction to Functional Grammar, Second Edition, London: Arnold, 1994.

[2] Grzegorek, M., "English sentences with introductory there and their Polish counterparts," in Fisiak, J. (ed.) Contrastive linguistics - prospects and problems, 143-170. Berlin: Walter de Gruyter \& Company, 1984.

[3] Hao Xuan Cao, Tiếng Việt - So thảo ngũ pháp chức năng (The Vietnamese Language - A Rough Draft on Functional Grammar), Hanoi: Publishing House of Social Sciences, 1991

[4] Stageberg, N. C. and Oaks, D. D., An Introductory English Grammar. Fifth Edition. Fort Worth, TX: Harcourt College Publishers, 2000.

[5] Biber, D.; Johansson, S.; Leech, G.; Conrad, S. and Finegan, E., Longman grammar of spoken and written English, London: Pearson Education Ltd, 1999.

[6] Longman Exams Dictionary. First edition, Harlow: Pearson Education Limited, 2006.

[7] Eastwood, J., Oxford guide to English grammar, Oxford: Oxford University Press, 1994.

[8] Breivik, L. E., "The use and non-use of 'existential there' in present-day English", Forum Linguisticum. Contributions to applied linguistics 2: 58-1-3, 1975; "Existential sentences revisited", Papers from the $4^{\text {th }}$ Scandinavian Conference of Linguistics, edited by K. Gregersen (Austin: University of Texas, 235-240, 1978.
[9] Thanh Minh To, Vai nghĩa trong câu trần thuật tiếng Việt và tiếng Anh (Semantic Roles in Vietnamese and English Declaratives), Ho Chi Minh City: Publishing House of Vietnam National University - Ho Chi Minh City, 2011.

[10] Alexander, L. G., Longman English Grammar Practice for Intermediate Students. Harlow: Longman Group UK Limited, 1990.

[11] Rando, E. and Napoli, D.J., "Definiteness in there-sentences," Language, 54, 300-313, 1978.

[12] Kimball J.P., "The grammar of existence," PCLS 9, 262-270, 1973.

[13] Li, Ch. and Thompson, S., "Subject and topic: A new typology of language," in Li, Ch. (ed.) Subject and Topic, New York: Academic Press, 1976.

[14] Dik, S.C., Functional grammar, Dordrecht-Holland: Foris Publications, 1978

[15] Thanh Minh To, "The English adverbial of time vs. the Vietnamese range topic of time," International Journal of Language and Linguistics. Vol. 2, No. 6, 348-355, 2014.

[16] Vietnam Committee of Social Sciences, Ngũ pháp tiếng Việt (Grammar of Vietnamese), Hanoi: Publishing House of Social Sciences, 1983.

[17] Thomson, A.J. and Martinet, A.V., A practical English grammar, Fourth edition, Oxford: Oxford University Press, 1986.

[18] Murphy, R., English grammar in use, Second edition, Cambridge: Cambridge University Press, 1994.

[19] Thanh Minh To, "Câu tổng loại trong tiếng Việt và tiếng Anh" (Generic sentences in Vietnamese and English), Language (Ngôn ngũ), 7(266), 27-40, 2011. 